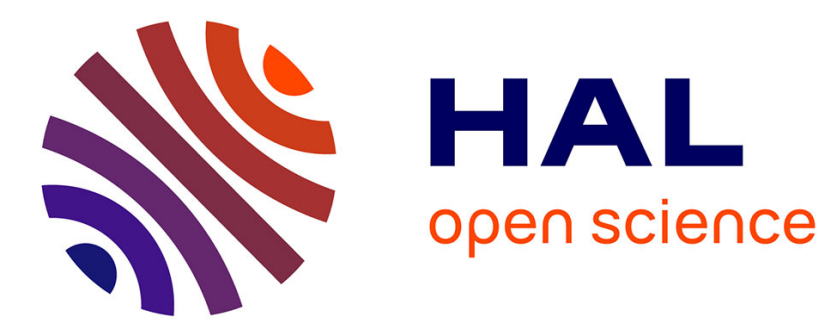

\title{
Concerning the first-order transition in the $\kappa$-phase (BEDT-TTF)4PtCl6 . C6H5CN
}

Marie-Liesse Doublet, Enric Canadell, Rimma Shibaeva

\section{To cite this version:}

Marie-Liesse Doublet, Enric Canadell, Rimma Shibaeva. Concerning the first-order transition in the $\kappa$-phase (BEDT-TTF)4PtCl6 . C6H5CN. Journal de Physique I, 1994, 4 (10), pp.1479-1490. 10.1051/jp1:1994202 . jpa-00247007

\section{HAL Id: jpa-00247007 https://hal.science/jpa-00247007}

Submitted on 1 Jan 1994

HAL is a multi-disciplinary open access archive for the deposit and dissemination of scientific research documents, whether they are published or not. The documents may come from teaching and research institutions in France or abroad, or from public or private research centers.
L'archive ouverte pluridisciplinaire HAL, est destinée au dépôt et à la diffusion de documents scientifiques de niveau recherche, publiés ou non, émanant des établissements d'enseignement et de recherche français ou étrangers, des laboratoires publics ou privés. 


\title{
Concerning the first-order transition in the $\kappa$-phase $(\mathrm{BEDT}-\mathrm{TTF})_{4} \mathrm{PtCl}_{6} \cdot \mathrm{C}_{6} \mathrm{H}_{5} \mathrm{CN}$
}

\author{
Marie-Liesse Doublet ('), Enric Canadell ( $\left.{ }^{1}\right)$ and Rimma P. Shibaeva ( $\left.{ }^{2}\right)$ \\ (') Laboratoire de Chimie Théorıque (`), Universıté de Parıs-Sud, 91405 Orsay Cedex, France \\ ${ }^{(2)}$ Institute of Solid State Physics, Russian Academy of Sciences, 142432 Chernogolovka. \\ Moscow District, Russia
}

(Received $19 \mathrm{Mav}$ 1994, accepted 4 Julv 1994)

\begin{abstract}
BEDT-TTF) $)_{4} \mathrm{PtCl}_{6} \cdot \mathrm{C}_{6} \mathrm{H}_{5} \mathrm{CN}$ is a $\kappa$-phase exhıbitıng a first-order transition at $250 \mathrm{~K}$. The crystal structure of this salt contains two different donor layers before the transition but only one after the transitıon. Every layer contains two different BEDT-TTF donor molecules. Our tıght binding band structure study suggests that this is the first BEDT-TTF salt contanning BEDT-TTF in three different oxidation states $(0,+1 / 2$ and +1$)$. One of the layers $(t-t)$ contains [BEDT-TTF" '] and [BEDT-TTF" $]_{2}$ dimers whereas the other layer ( $B$ ) contans two different [BEDT-TTF ${ }^{1}{ }^{\prime} \mathrm{I}_{2}$ dimers. We suggest that the first-order transition is associated with the disproportionation of the two [BEDT-TTF $\left.{ }^{1}{ }^{\prime}\right]_{2}$ dimers of layer $B$ in $\left[\text { [BEDT-TTF }{ }^{+1}\right]_{2}$ and [BEDT-TTF $\left.{ }^{\prime \prime}\right]_{2}$ dimers. This process is assoclated with a conformational change in one of the dimers which apparently optımızes the donor-acceptor interactions in this $\kappa$-phase. According to the present results it would be worthwhile to reexamine the transport properties of this salt.
\end{abstract}

Among the many charge transfer salts presently known, the so called $\kappa$-phases have not only led to the highest superconducting transition temperatures [1] (excluding fullerenes) but have also given a seemingly endless series of electronic surprises. The transport properties of these salts seem to be extremely dependent on small changes in pressure, temperature, disorder or chemical environment $[2,3]$. For instance, whereas at ambient pressure $\kappa-\mathrm{BEDT}-\mathrm{TTF}_{2} \mathrm{Cu}\left[\mathrm{N}(\mathrm{CN})_{2}\right] \mathrm{Br}$ [4] and $\kappa-\mathrm{BEDT}-\mathrm{TTF}_{2} \mathrm{Cu}\left[\mathrm{N}(\mathrm{CN})_{2}\right] \mathrm{Cl}_{0}{ }_{5} \mathrm{Br}_{0,5}$ [5] (where BEDT-TTF means bis(ethylenedithio)tetrathiafulvalene, 1) are superconductors,

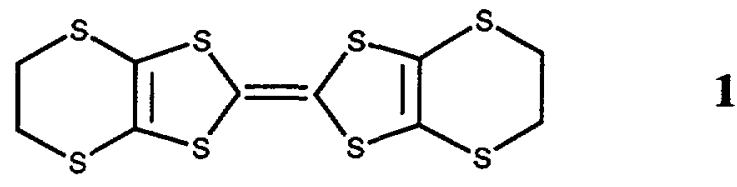

BEDT-TTF

(*) CNRS URA 506. 
$\kappa$-BEDT-TTF ${ }_{2} \mathrm{Cu}\left[\mathrm{N}(\mathrm{CN})_{2}\right] \mathrm{Cl}[6]$ is a semiconductor. However a very small applied pressure $(0.3 \mathrm{kbar})$ is enough to make the latter superconducting [6]. The calculated band structures for the donor slabs of the two salts $\kappa$-(MDT-TTF $)_{2} \mathrm{AuI}_{2}$ |7| (MDT-TTF : (ethylenedithio)tetrathiafulvalene $)$ and $\kappa-\left(\text { EDT-TTF }\left(\mathrm{CH}_{2} \mathrm{OH}\right)\right)_{2} \mathrm{ClO}_{4}^{8}\left(\right.$ EDT $\left.-\mathrm{TTF}\left(\mathrm{CH}_{2} \mathrm{OH}\right)\right)$ : (ethylenedithio hydroxymethyl)tetrathiafulvalene) are almost indistinguishable $[8,9]$ meaning that the different donor $\cdots$ donor interactions in these slabs are extremely similar, and yet the first is metallic and superconductıng at $4.5 \mathrm{~K}$ [7] whereas the second is insulatıng [8]. The corollary of these and many other similar observations is that the $\kappa$-phases probably lie at the bordelıne of the valıdity range of the delocalized and localized descriptions of their electronic structure.

(BEDT-TTF $)_{4} \mathrm{PtCl}_{6} \cdot \mathrm{C}_{6} \mathrm{H}_{5} \mathrm{CN}[10,11]$ is an intriguing addition to the growing arsenal of $\kappa$ phases. This salt undergoes a first-order transition at $250 \mathrm{~K}$ after which it becomes insulating [10]. The temperature dependence of the conductivity before the transition is very weak although it seems it is weakly activated. This contrasts with the fact that during the same temperature range it shows temperature independent paramagnetıc susceptibility [10], as if it was metallic. An interesting feature of the $250 \mathrm{~K}$ transition is the associated change in the crystal structure. The unit cell of (BEDT-TTF) $)_{4} \mathrm{PtCl}_{6} \quad \mathrm{C}_{6} \mathrm{H}_{5} \mathrm{CN}$ before the transition contains two nonequivalent cation slabs whereas after the transition the two slabs become identıcal. In this paper we report our study of the crystal and electronic structures of (BEDT-TTF $)_{4} \mathrm{PtCl}_{6} \cdot \mathrm{C}_{6} \mathrm{H}_{5} \mathrm{CN}$ at $293 \mathrm{~K}$ and $218 \mathrm{~K}$, i.e., before and after the transition. in order to unravel the origin of the first-order transition and to provide some rationale for the reported physical propertıes of this salt. Our study suggests that the transition in $(\mathrm{BEDT}-\mathrm{TTF})_{4} \mathrm{PtCl}_{6} \cdot \mathrm{C}_{6} \mathrm{H}_{5} \mathrm{CN}$ is quite unique among the $\kappa$-phases.

\section{Crystal structure of (BEDT-TTF $)_{4} \mathrm{PtCl}_{6} \cdot \mathrm{C}_{6} \mathrm{H}_{5} \mathrm{CN}$ before $(293 \mathrm{~K})$ and after $(218 \mathrm{~K})$ the first- order transition.}

A projection of the $293 \mathrm{~K}$ crystal structure of (BEDT-TTF) ${ }_{4} \mathrm{PtCl}_{6} \cdot \mathrm{C}_{6} \mathrm{H}_{5} \mathrm{CN}$ along the $u$ direction is shown in figure 1 BEDT-TTF cation radical layers parallel to the $a b$ plane alternate with layers of $\mathrm{PtCl}_{6}^{2-}$ and $\mathrm{C}_{6} \mathrm{H}_{5} \mathrm{CN}$ along the $c$ direction. As shown in figure 2 which is a projection view of one of the donor layers along the direction of the central $\mathrm{C}=\mathrm{C}$ bond, the BEDT-TTF layers are built from almost orthogonal BEDT-TTF dimers, as in the usual $\kappa$ phases. However, in the present case the two BEDT-TTF slabs are crystallographically nonequivalent layer th contains centrosymmetric dimers $\left(I-I_{1}\right)$ and $\left(I I-I_{1}\right)$ whereas layer $\mathfrak{B}$ contains centrosymmetric dimers (III-III $)_{1}$ and (IV-IV, ). In layer tt one of the two ethylene groups of II is disordered whereas in layer $\mathcal{B}$ the two ethylene groups of both III and IV are disordered [11].

The cation radical sublattice of (BEDT-TTF $)_{4} \mathrm{PtCl}_{6} \cdot \mathrm{C}_{6} \mathrm{H}_{5} \mathrm{CN}$ at $2 \mathrm{I} 8 \mathrm{~K}$, i.e., after the firstorder transition, is such that the two BEDT-TTF layers become identical. I and II are related by a translation $c^{\prime}=c / 2$ with III and IV. Thus, the cation sublattice of the $218 \mathrm{~K}$ structure has a periodicity of $c^{\prime}=c / 2$ perpendicular to the cation radical layers [11]. The ethylene groups of both I and II do not exhibit any disorder. As shown in table I, where the unit cell parameters of the $293 \mathrm{~K}$ and $218 \mathrm{~K}$ structures are reported, the remainıng changes are quite small except for a slight decrease of the total volume.

To summarize, although by construction of its cation radical slabs, (BEDTTTF) $)_{4} \mathrm{PtCl}_{6} \cdot \mathrm{C}_{6} \mathrm{H}_{5} \mathrm{CN}$ belongs to the general class of the $\kappa$-phases, there is a noticeable difference with all other BEDT-TTF salts of this family. In (BEDT-TTF) ${ }_{4} \mathrm{PtCl}_{6} \cdot \mathrm{C}_{6} \mathrm{H}_{5} \mathrm{CN}$ the two almost orthogonal dimers which constitute the elemental motif of the cation radical layers are non equivalent both crystallographically and in terms of the intradimer mode of overlap. This leads to the very low symmetry of the crystal structure (space groupe $\mathrm{P} \overline{1}$ ) which 


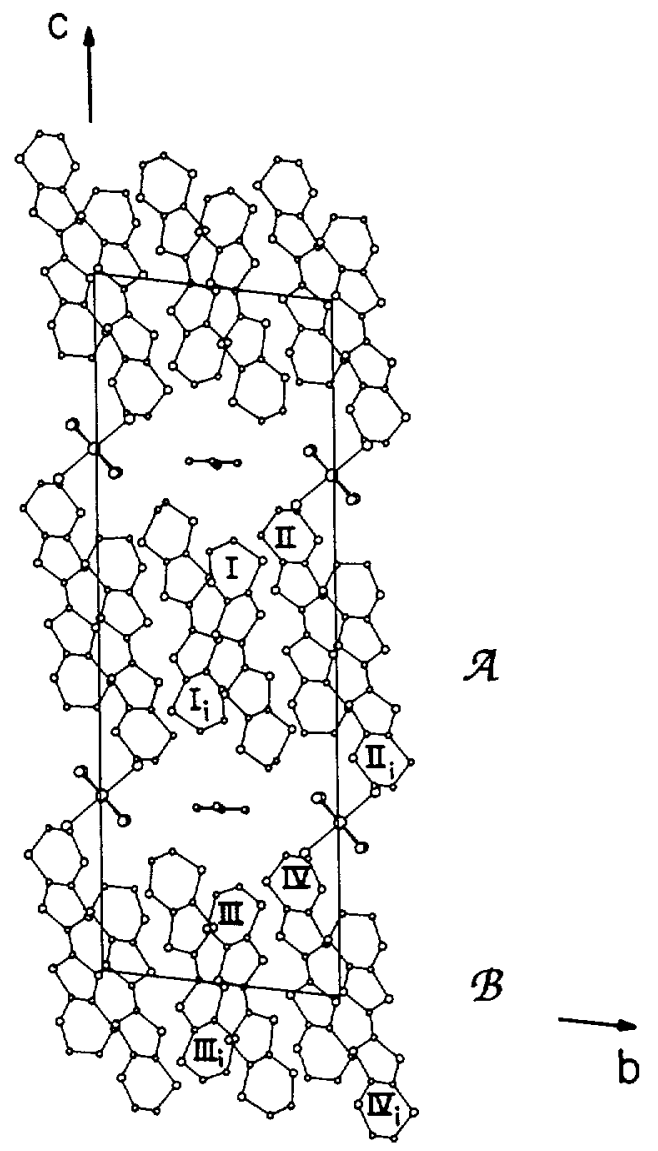

Fig. 1. - Projection along the $a$ direction of the $293 \mathrm{~K}$ crystal structure of (BEDT-TTF) ${ }_{4} \mathrm{PtCl}_{6} \cdot \mathrm{C}_{6} \mathrm{H}_{5} \mathrm{CN}$. The four different types of BEDT-TTF centrosymmetric dimers (I-I) (II $\left.\mathrm{II}_{1}\right)\left(\mathrm{III}-\mathrm{III}_{1}\right)$ and $\left(\mathrm{IV}-\mathrm{IV}_{1}\right)$ are indicated.

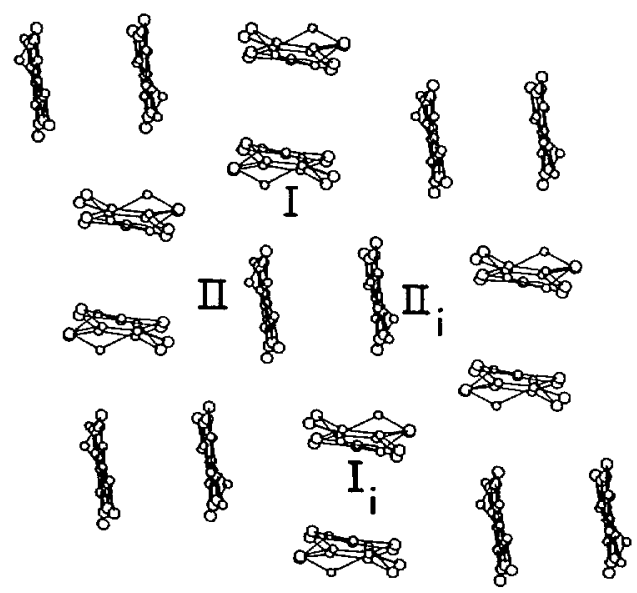

Fig. 2. - Projection view of one of the donor layers in (BEDT-TTF) $)_{4} \mathrm{PtCl}_{6} \quad \mathrm{C}_{6} \mathrm{H}_{5} \mathrm{CN}$ along the direction of the central $\mathrm{C}=\mathrm{C}$ bond of the donors showing the typical $\kappa$-phase topology. 
Table I - Unt cell parameters for (BEDT-TTF) ${ }_{4} \mathrm{PtCl}_{6} \quad \mathrm{C}_{6} \mathrm{H}_{5} \mathrm{CN}$ at $293 \mathrm{~K}$ and $218 \mathrm{~K}$.

\begin{tabular}{|c|c|c|}
\hline & \multicolumn{1}{|c|}{$293 \mathrm{~K}$} & \multicolumn{1}{|c|}{$218 \mathrm{~K}(*)$} \\
\hline$a(\AA)$ & $8.661(2)$ & $8.582(3)$ \\
$b(\AA)$ & $11.960(5)$ & $11.891(6)$ \\
$c(\AA)$ & $34.690(7)$ & $17.512(4)$ \\
$\alpha\left(\left(^{\circ}\right)\right.$ & $82.97(3)$ & $81.55(3)$ \\
$\beta\left({ }^{\circ}\right)$ & $87.21(2)$ & $86.65(2)$ \\
$\gamma\left(\left(^{\circ}\right)\right.$ & $94.97(3)$ & $94.44(3)$ \\
$V^{\prime}\left(\AA^{3}\right)$ & 3546 & 1758 \\
\hline
\end{tabular}

(`) The parameters for the cation sublattice are given.

distinguishes the present salt from the other BEDT-TTF $\kappa$-phases. How this non equivalence affects the electronic structure of this salt $\mathrm{is}$ considered in detail in the next section. Finally it is worth mentioning that (BEDT-TTF) ${ }_{4} \mathrm{PtCl}_{6} \cdot \mathrm{C}_{6} \mathrm{H}_{5} \mathrm{CN}$ is the first $\kappa$-phase exhibiting a turstorder phase transition.

\section{Electronic structure of (BEDT-TTF) ${ }_{4} \mathrm{PtCl}_{6} \cdot \mathrm{C}_{6} \mathrm{H}_{5} \mathrm{CN}$ and origin of the first-order transition.}

In order to understand the origin of the $250 \mathrm{~K}$ transition and how the structural changes noted in the previous section are related to the change in the transport properties, we have studied the electronic structure of the BEDT-TTF layers before and after the transtion. Our tight-binding band structure calculatıons [12] use an extended Hückel type Hamıltonian [13] and a double- $\zeta$ basts set [14] for all atoms except hydrogen. The exponents, contraction coefficients and parameters were taken from previous work [15].

A. Electronic structure after the transition. - After the $250 \mathrm{~K}$ transition, the cation tadical sublattice contains just one type of BEDT-TTF layer built from two BEDT-TTF dimers. With the formal oxidation required by the stoichiometric formula, (BEDT-TTF) $)_{4}^{-}$, there are six electrons per unit cell to fill the four HOMO bands. In contrast with the other $\kappa$ phases, the two BEDT-TTF dimers of the layer are crystallographically non equivalent so that

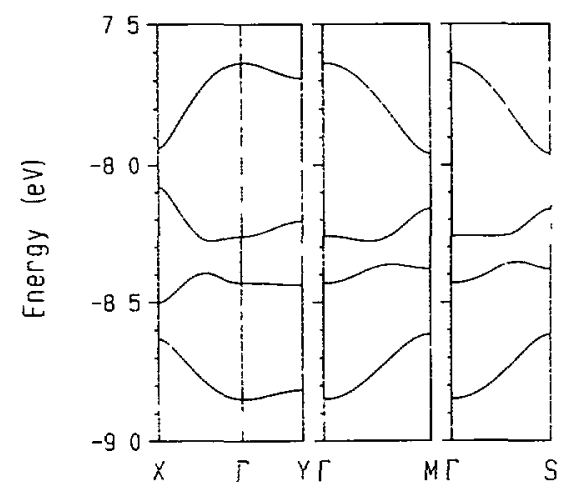

Fig. 3. - Dispersion relations for the HOMO bands of the donor slab in (BEDT-TTF $)_{4} \mathrm{PtCl}_{\mathrm{t}} \mathrm{C}_{4} \mathrm{H}_{4} \mathrm{CN}$ It $218 \mathrm{~K}, I, X, Y, M$ and $S$ refer to the wave vectors $(0,0),(a / 2,0),(0 \mathrm{~b} / 2),(a / 2$, $b / 2),(-a / 2, b / 2)$, iespectively. 
there is no symmetry reason why the third and fourth bands (from bottom) should be degenerate at the border of the Brillouin zone leading to a metallic type filling. Thus it is not clear whether there is or not a band gap between these bands. The calculated band structure for the BEDT-TTF slabs of (BEDT-TTF) ${ }_{4} \mathrm{PtCl}_{6} \quad \mathrm{C}_{6} \mathrm{H}_{5} \mathrm{CN}$ using the crystal structure at $218 \mathrm{~K}$ is reported in figure 3. The upper HOMO band is clearly separated from the next lower one by a band gap. Calculations for the full Brillouın zone confirm the existence of a band gap of $0.12 \mathrm{eV}$. This result is in agreement with the activated conductivity and susceptibility behavior of (BEDT-TTF $)_{4} \mathrm{PtCl}_{6} \quad \mathrm{C}_{6} \mathrm{H}_{5} \mathrm{CN}$ after the $250 \mathrm{~K}$ transition [10].

B. Electronic STRUCTURE BEFORE THE TRANSITION. - The calculated dispersion relations for layers tt and $\mathfrak{B}$ of the crystal structure of (BEDT-TTF ) ${ }_{4} \mathrm{PtCl}_{6} \quad \mathrm{C}_{6} \mathrm{H}_{5} \mathrm{CN}$ at $293 \mathrm{~K}$ are shown In figures $4 \mathrm{a}$ and $4 \mathrm{~b}$, respectively. Although much smaller $(0.02 \mathrm{eV})$, there is also a band gap between the third and fourth bands from botton of the donor layer tt (Fig. 4a). In this and almost every other detail, the band structure of the donor layers after the transition (Fig. 3) and that of layer tt before the transition (Fig. 4a) are extremely similar. The calculated band structure for layer $\mathcal{B}$ of the $293 \mathrm{~K}$ structure is however very different. The two higher HOMO bands overlap so that the Fermı level for an electron fillıng of (BEDT-TTF) ${ }_{+}^{+}$(shown as a dotted line in Fig. 4b) cuts both of these bands. Thus the associated Fermı surface (shown in

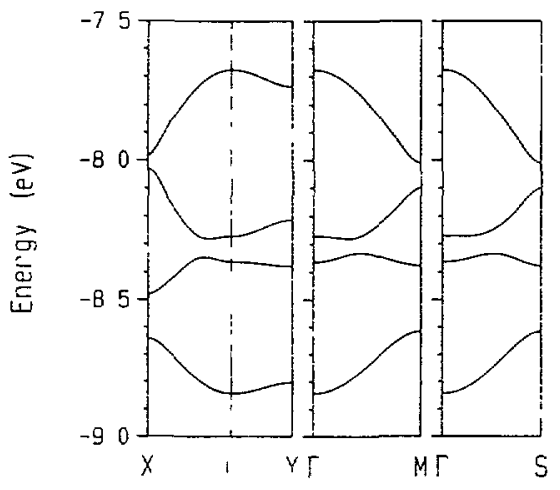

(a)

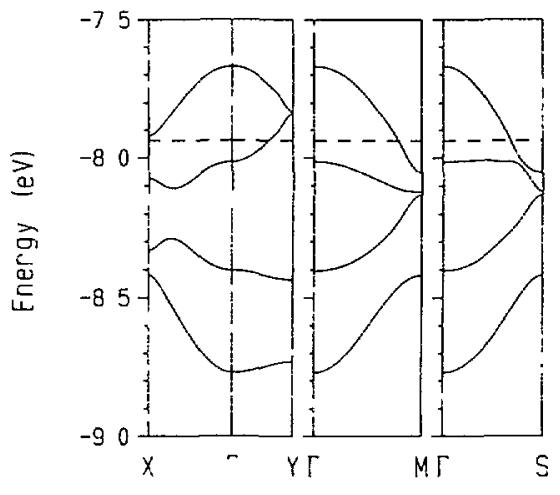

(b)

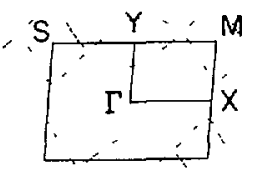

(c)

Fig. 4. - Dispersion relations for the HOMO bands of (a) layer $t$ and (b) layer $B$ of (BEDT-TTF) $)_{4} \mathrm{PtCl}_{6}, \mathrm{C}_{6} \mathrm{H}_{5} \mathrm{CN}$ at $293 \mathrm{~K}, \quad I, X, Y, M$ and $S$ refer 10 the wave vectors (0.0) $(a / 2,0)(0, b / 2),(a / 2, b / 2),(-a / 2, b / 2)$. respectively. The dotted line in $(b)$ refers to the Ferm level. (c) Fermı surtace associated with the partlally tilled bands of (b). 
Fig. 4c) contains hole pockets centered at $Y$ and electron pockets centered at $M$. This Fermı surface differs from all other Fermı surfaces reported for BEDT-TTF $\kappa$-phases in that both the electron and hole pockets are closed [9].

C. BEDT-TTF OXIDATION STATES AND DONOR ... DONOR INTERACTIONS. - The previous results clearly show that the $250 \mathrm{~K}$ transition is maınly associated with the opening of a band gap for layer $\beta$ of the room temperature structure. Opening of a band gap between to overlapping bands is usually associated with modifications of the donor $\cdots$ donor intermolecular interactions. Thus, in order to discuss the origin of the $250 \mathrm{~K}$ transition we report in table II the

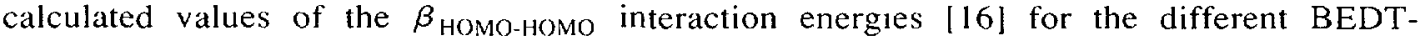
TTF ... BEDT-TTF intermolecular interactions associated with $\mathrm{S}$... S contacts shorter than $4.0 \AA$ in the $218 \mathrm{~K}$ and $293 \mathrm{~K}$ structures of (BEDT-TTF $)_{4} \mathrm{PtCl}_{6} \quad \mathrm{C}_{6} \mathrm{H}_{5} \mathrm{CN}$. These interaction energies reflect the strength of the interaction between a pair of BEDT-TTF HOMOs in adjacent sites of the crystal and give important information relating the crystal and electronıc

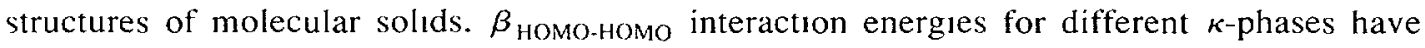
also been reported by Whangbo et al. [9].

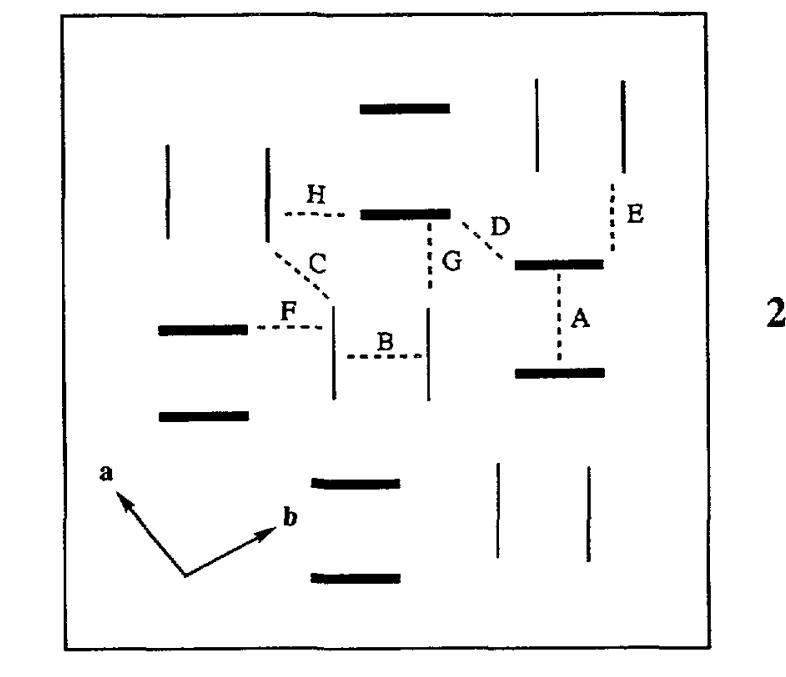

If the slabs 2 are viewed as being built from parallel chains of BEDT-TTF dimers along approximately the a-direction, the different interaction energies in table II can be classified in three different groups : (a) those associated with intradimer interactions $(A$ and $B)$, (b) those associated with interdimer intrachain interactions $(C$ and $D$ ), and (c) those associated with interdimer interchain interactions $(E, F, G$ and $H$ ). According to the calculated values of table II, the intradimer interactions are always considerably larger than both the interchain and intrachain interdimer interactions. This is not always the case as shown by the $\beta_{\text {номо-номо }}$ interaction energies reported by Whangbo et al. [9]. For instance, there is no net separation between the interchain and intrachain interdimer interactions for $\kappa-(\mathrm{BEDT}-\mathrm{TTF})_{2} \mathrm{Cu}(\mathrm{NCS})_{2}$ or $\kappa$-(BEDT-TTF $)_{2} \mathrm{I}_{3}$. The situation for the present salt is however quite similar to that of $\kappa$-(MDT-TTF $)_{2} \mathrm{AuI}_{2}$ [9] which is metallic and superconductıng at $4.5 \mathrm{~K}$ [7]. In the present 
context, however, the important result of table II is that there are very large changes in the intradimer interactions whereas most of the interdimer interactions remain remarkably constant. This strongly suggests that the reason for the gap opening at $250 \mathrm{~K}$ is to be found in the inner structure of the different dimers and not in the interdimer interactions.

Shown in figure 5 are two different views of the four dimers $\left(I-I_{1}\right),\left(I I-I_{1}\right),($ III-III $)$ and (IV$I_{1}$ ) found in the crystal structure at $293 \mathrm{~K}$. Those of the crystal structure at $218 \mathrm{~K}$ are very similar to those of figures $5 \mathrm{a}$ and $5 \mathrm{~b}$ and thus are not shown. Let us recall that dimers (I-I $)$ (Fig. 5a) and (II-II, ) (Fig. 5b) are those of layer tt before the transition and also those of the salt after the transition, whereas dimers (III-III) (Fig. 5c) and (IV-IV, ) (Fig. 5d) are those of layer $\mathcal{B}$ before the transition. The dimers in figures $5 \mathrm{a}$ and $5 \mathrm{c}$ are of the so-called bond-over-ring type. This is the dimer overlap mode found in almost all $k$-phases presently known. The dimers of figures $5 \mathrm{~b}$ and $5 \mathrm{~d}$ are also of the bond-over-ring type, but now, the central $\mathrm{C}=\mathrm{C}$ bond of one donor 1 s over a six membered ring of the other donor, in contrast with those of figures $5 \mathrm{a}$ and $5 \mathrm{c}$, where the central $\mathrm{C}=\mathrm{C}$ bond of one donor is over a five membered ring of the other donor. Thus the top projection views of figure 5 suggest that the overlap modes of dimers (II-II, ) (Fig. 5b) of layer $t$ and (IV-IV $)$ (Fig. 5d) of layer $\mathcal{B}$ are simılar as are those of dimers (I-I) (Fig. 5a) of layer $t$ and (III-III) (Fig. 5c) of layer $\mathfrak{B}_{1}$. The side views of figure 5 reveal however an interestıng difference : whereas the dimers (II-II $)$ and $\left(I V-I V_{1}\right)$ are effectively very similar, the dimers $\left(\mathbf{I}-\mathbf{I}_{1}\right)$ and $\left(\mathbf{I I I}-\mathrm{III}_{1}\right)$ are very different despite the similar overlap mode. It is to be noted that the $\beta$ interaction energies of table II are quite simılar for dimers (II-II) and (IV-

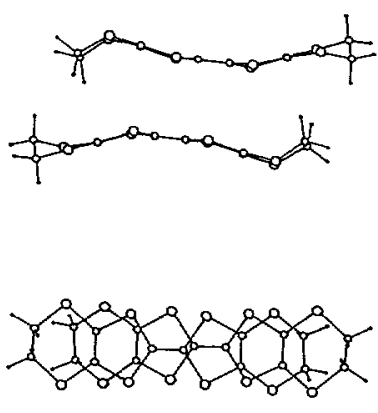

(a)

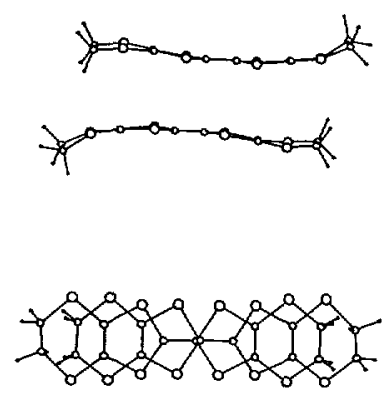

(c)
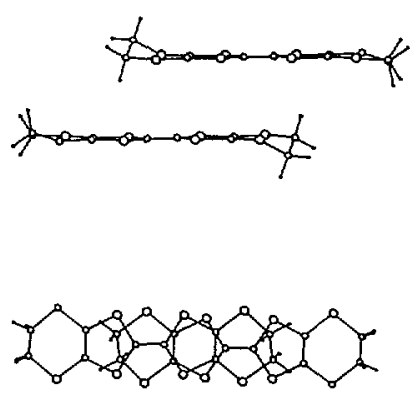

(b)

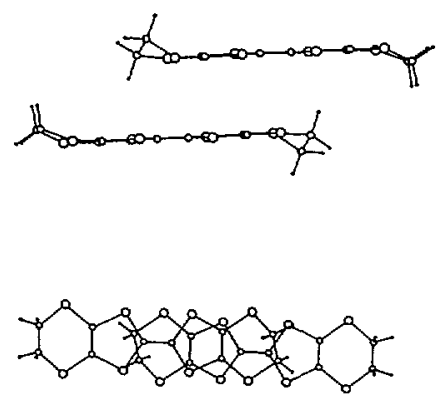

(d)

Fig. 5. - Two different projection views of the BEDT-TTF dımers in the $293 \mathrm{~K}$ structure of (BEDT-TTF $)_{4} \mathrm{PtCl}_{6} \mathrm{C}_{6} \mathrm{H}_{5} \mathrm{CN}$ : (a) (I $\left.\mathrm{I}_{1}\right)$ (b) $\left(\mathrm{II} \mathrm{II}_{1}\right)$ (c) (III-III $)$ and (d) (IV-IV $)$. 
$\left.I_{1}\right)$ at $293 \mathrm{~K}$, i.e., $0.308 \mathrm{is.} 0.266$, but quite different for dimers $\left(\mathrm{I}_{-} \mathrm{I}_{1}\right)$ and (III-III $)$, i.e., 0.340 v's. 0.504. Thus, it is tempting to associate the $250 \mathrm{~K}$ transition with the intradimer change occurring in dimer (III-III $)_{1}$ ) of layer $\mathcal{B}$.

The dimer $\left(I-I_{1}\right)$ is completely different from the other three dimers of figure 5 , because of both the different conformation of the six membered rings and the quite strong deviation from planarity of the $\pi$ framework of BEDT-TTF. As a matter of fact, the dimer shown in figure 5 a is the same found in the crystal structure of neutral BEDT-TTF [17]. This immediately suggests that dinner $\left(\mathrm{I}-\mathrm{I}_{1}\right)$ of layer $-t$ at $293 \mathrm{~K}$ is build from two BEDT-TTF ${ }^{\prime}$ molecules and consequently that dimer (II-II) of the same layer is build from two BEDT-TTF ${ }^{+}$cations. Thus, (BEDT-TTF) ${ }_{4} \mathrm{PtCl}_{6} \cdot \mathrm{C}_{6} \mathrm{H}_{5} \mathrm{CN}$ would be the first BEDT-TTF charge transfer salt containing the basic structural motif of neutral BEDT-TTF, i.e., the $\left[\text { BEDT-TTF }{ }_{2}^{0}\right]_{2}$ dimer. This receives strong support from examination of the central $\mathrm{C}=\mathrm{C}$ bond distances in the crystal structure at $293 \mathrm{~K}$. The distance is noticeably shorter for I ( $1.338 \AA$ ) than for II ( $1374 \AA$ ). The same is true for the $218 \mathrm{~K}$ structure : $1.341 \AA$ for I and $1.378 \AA$ for II. As a comparison, the distances found for BEDT-TTF ${ }^{+}$in (BEDT-TTF) $\mathrm{Ag}_{4}(\mathrm{CN})_{5}[18]$ and BEDT-TTF ${ }^{\circ}$ in neutral BEDT-TTF [17] are $1.38 \AA$ and $1.32 \AA$, respectively. By contrast, the central $\mathrm{C}=\mathrm{C}$ bond distances found in the dimers $($ III-III $)$ and (IV-IV $)$ of layer $B$ at $293 \mathrm{~K}$ are quite similar: $1.364 \AA$ for III and $1370 \AA$ for IV. These values are not only quite similar but also very close to those found for (BEDT-TTF) $)^{1 / 2+}$ in $\beta$-BEDT-TTF $I_{2}$ (1.362 $\AA$ ) [19]. All these observations suggest that BEDT-TTF is found in three different oxidation states $(0,+1 / 2$ and +1$)$ in the room temperature crystal structure of (BEDT-TTF) ${ }_{4} \mathrm{PtCl}_{6} \cdot \mathrm{C}_{6} \mathrm{H}_{5} \mathrm{CN}$.

Suggestive as it may be, the previous crystal structure analysis can not be taken as conclusive. In order to have a more quantitative basis for our interpretation we need to consider the electronic structure of the BEDT-TTF dimers. Every BEDT-TTF HOMO leads to a bondıng $\left(\mathrm{HOMO}_{+}\right)$and a antıbonding ( $\mathrm{HOMO}$ ) combinations for the dimer. Shown in figures 6a-d are the molecular orbital diagrams for the dimers shown in figures 5a-d, respectively. At the right of each diagram we report the HOMO level of the monomer and at left the HOMO and HOMO levels of the dimer. A first observation is that the HOMO levels of III and IV are quite similar $(0.1 \mathrm{eV})$ whereas there is a large energy difference between those of I and II $(0.5 \mathrm{eV})$. In addition, the HOMO of II is the highest. As noted before the overlap mode of dimers (II-II $)$ and (IV-IV $)$ are similar and so are the calculated $\beta$ interaction energies. The overlap mode of dimers (I-I $)_{1}$ and (III-III $)_{1}$ ) is also similar but the $\beta$ interaction energies are quite different. This is due to the nonplanarity of the $\pi$ backbone in I which makes the interaction sizeably smaller. The final outcome is that the HOMO_levels of the two dimers in layer $\xi \beta$ lie at very similar energies (see Figs. $6 c$ and $6 \mathrm{~d}$ ), whereas there is a large energy difference between the HOMO_ levels of the two dimers in layer $t$ (see Figs. 6a and 6b). This is a significant result because they are the $\mathrm{HOMO}_{-}$levels which are going to lead to the highest HOMO band of the layer, 1 e. the empty band in figure $4 a$. When two levels on neighboring dimers interact, the mixing between the two levels 1s, as a first approximation, directly proportional to the interaction matrix element and inversely proportional to the energy difference between the two levels $[20 \mathrm{~J}$. Since, as shown by the results of table II, the interaction matrix elements are similar for layers it and $\mathcal{S}, 1$ is the energy difference between the dimer levels which plays the leading role in determınıng the degree of mixing of these levels. The HOMO_ levels of figures $6 \mathrm{c}$ and $6 \mathrm{~d}$ are not far apart so that the HOMO_ levels of the two different dimers of layer $\mathcal{B} \operatorname{mix}$ strongly to lead to the higher HOMO bands of figure $4 \mathrm{~b}$. Thus, both dimers (III-III $)$ and (IV-IV $)$ contribute with a comparable weight to the wave functions associated with the empty band wave vectors of figure $4 \mathrm{~b}, \mathrm{i}$ e., the oxidation state of the donors III and IV is $+1 / 2$. By contrast, there is an important energy difference between the HOMO_ levels of figures $6 \mathrm{a}$ and $6 \mathrm{~b}$ which is quite large compared with the 


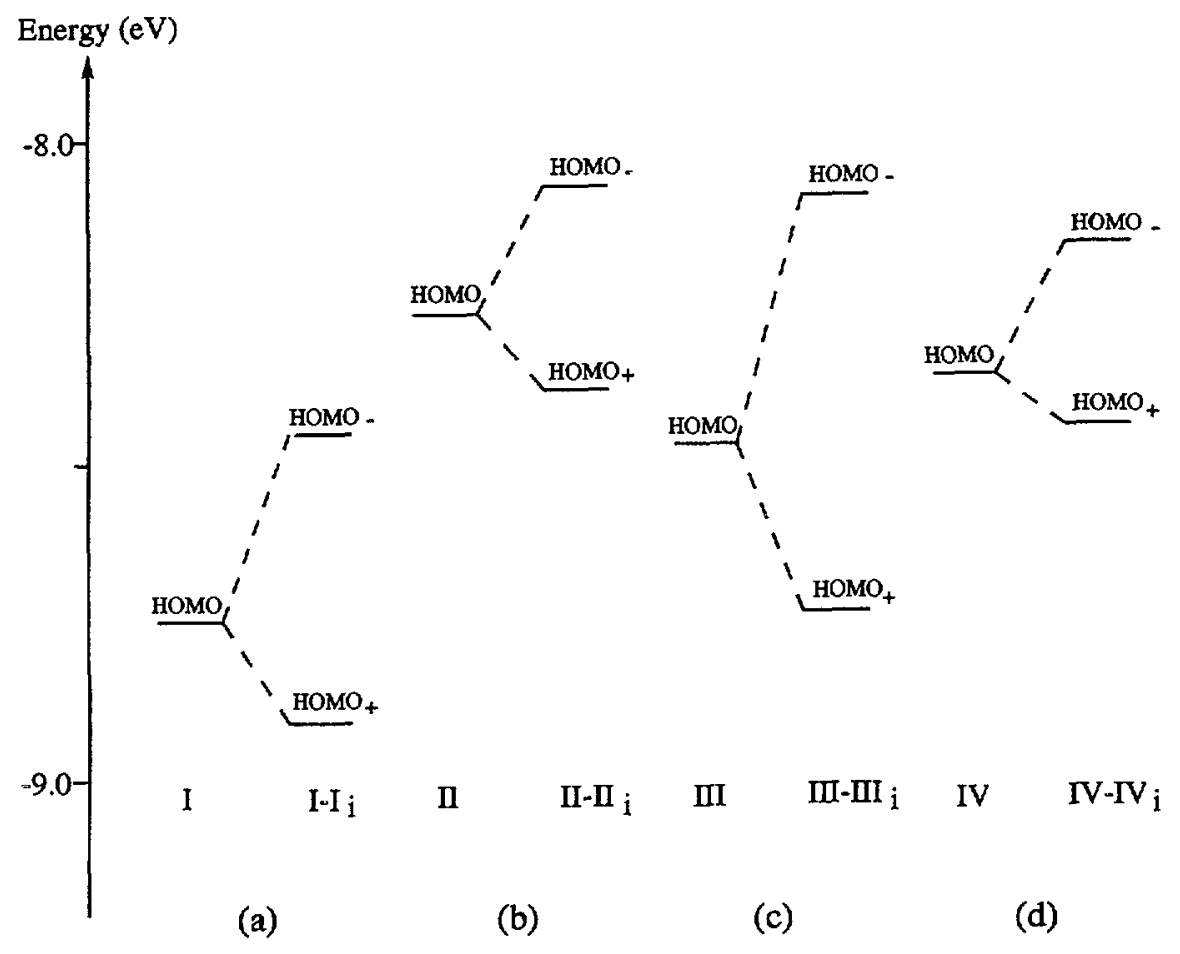

Fig. 6. - Molecular orbital diagrams for the BEDT-TTF dimers in the $293 \mathrm{~K}$ structure of

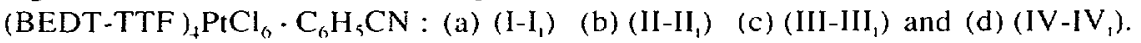

interdimer interchain interaction matrıx elements [21]. As a consequence, the HOMO_levels of the two different dimers practically do not mix and the highest band of figure $4 \mathrm{a}$, which is empty, is made of the HOMO levels of dimer (II- $\left.\mathrm{II}_{4}\right)$ whereas the band build from the HOMO_ levels of dimer $\left(\mathbf{I}-\mathbf{I}_{1}\right)$ is full Consequently, the oxidation state of the donors I and II are 0 and +1 , respectively.

D. ORIGIN OF THE TRANSITION AND PHYSICAL PROPERTIES OF (BEDT-TTF) $4 \mathrm{PtCl}_{6} \cdot \mathrm{C}_{6} \mathrm{H}_{5} \mathrm{CN}$. - It is clear from our results (see Figs. 3, 4a and $4 \mathrm{~b}$ ) that the transition at $250 \mathrm{~K}$ is associated with the opening of a band gap in layer $\mathcal{B}$. The simılarity of the interdimer interaction energies of table II suggests that it is not a change in the interdimer interactions which is responsible for the opening of this band gap. Our study of the geometrical and electronic structure of the different dimers clearly shows that the opening of the band gap is associated with the change on the oxidation state of the donors III and IV of layer $\beta$ from $+1 / 2$ to 0 and +1 , respectively. Thus, the transition is associated with a stmitural localization [22] as opposed to the electronc localization which is believed to be at the origin of the nonmetallic properties of other $\kappa$-phases. The question which remains to be answered is: what is the driving force for this structural localization? It could be thought that the disproportionation of two $\left[\text { BEDT }-\mathrm{TTF}^{+1 / 2}\right]_{2}$ dimers in one $\left[\mathrm{BEDT}-\mathrm{TTF}^{+1}\right]_{2}$ and one [BEDT-TTF $\left.{ }^{0}\right]_{2}$ is the essentia] factor lowerıng the energy of the system. We consıder unlıkely this possıbility because in that case it is not easy to understand why such phenomenon has not already been observed in the many existing $\kappa$-phase salts. 
Table II. - Absolute values of the $\beta_{\text {номо-номо interaction energies (eV) calculated for the }}$ different BEDT-TTF ... BEDT-TTF interactions in the $218 \mathrm{~K}$ and $293 \mathrm{~K}$ crystal structures of (BEDT-TTF) ${ }_{4} \mathrm{PtCl}_{6} \cdot \mathrm{C}_{6} \mathrm{H}_{5} \mathrm{CN}$ (see 2 for labelling).

\begin{tabular}{|c|c|c|c|}
\hline \multirow{2}{*}{ Interaction } & \multicolumn{2}{|c|}{$293 \mathrm{~K}$ structure } & \multirow{2}{*}{$218 \mathrm{~K}$ structure } \\
\cline { 2 - 4 } & layer tt & layer $\mathcal{B}$ & \\
\hline$A$ & 0.340 & 0.504 & 0.402 \\
$B$ & 0.308 & 0.266 & 0.343 \\
$C$ & 0.207 & 0.208 & 0.203 \\
$D$ & 0.145 & 0.191 & 0.155 \\
$E$ & 0.098 & 0.111 & 0.091 \\
$F$ & 0.090 & 0.099 & 0.079 \\
$G$ & 0.067 & 0.018 & 0.068 \\
$H$ & 0.054 & 0.068 & 0.063 \\
\hline
\end{tabular}

Until now we have completely disregarded the role of the $\mathrm{PtCl}_{6}^{2}-$ anions. Our calculations show that the energy levels of $\mathrm{PtCl}_{6}^{2-}$ are practically identical before and after the transition. Thus a change in the anions structure which induces the disproportionation in the donor layer should also be discarded. The only remainıng possibility is that the disproportionatıon is induced in the donor slab to optımize the donor-acceptor interactions. We recall that the disproportionation is associated with a strong conformational change in the two donors of dimer $(\text { III-III })_{1}$ ) to adopt the structure of neutral BEDT-TTF. A detalled analysis of the short donor-acceptor contacts before and after the transition strongly suggests that this is indeed the most likely possibility. All the short $\mathrm{S} \ldots \mathrm{Cl}$ contacts before and after the transition are associated with the six-membered ring sulfur atoms. These contacts before the transition are : $3.433,3.410,3.635,3.474 \AA$ and are associated with the donors I II, III and IV, respectively. The short contacts after the transition become $3.404,3.413,3.404,3.413 \AA$ for the same donors, respectively. Thus there is almost no change for the donors of layer tf but a large change for donor III of layer $\mathcal{B}$. This shortening coupled with the conformational change of the $\mathrm{CH}_{2}-\mathrm{CH}_{2}$ group of the six membered ring in donor III leads to much better $\mathrm{H}$.. Cl hydrogen bonding interactions which stabilize the low temperature structure. We believe this is the driving force for the $250 \mathrm{~K}$ first-order transition.

Finally, let us comment on the physical propertses of (BEDT-TTF) ${ }_{4} \mathrm{PtCl}_{6} \cdot \mathrm{C}_{6} \mathrm{H}_{5} \mathrm{CN}$. According to our calculations, this salt should be metallic before the transition and non magnetıc and insulatıng after the transitıon. The conductıvity and magnetıc susceptubility measurements after the transition [10] agree with our results. The transport properties before the transition are more puzzling because it is reported that the salt has weakly activated conductıvity but temperature independent paramagnetıc susceptıbility [10]. We believe the temperature independent paramagnetic susceptibility is associated with layer $\mathscr{B}$. The origin of the weakly activated conductivity is unclear. It could be an artifact due to the relatively small number of data points. By analogy with other $\kappa$-phases, it can be thought that the disorder on the external $\mathrm{CH}_{2}-\mathrm{CH}_{2}$ groups of the layer $\mathcal{B}_{\text {donors }}$ is enough to suppress the metallic properties of the layer although the conductivity remains high. In such a case, the electrons would probably be localized in the dimers, which from the electronic viewpoint are the 
essential units of the layer, so that the global charge per dimer will be +1 and the disproportionation mechanism would still be valid. In that case the decrease in conductivity at $250 \mathrm{~K}$ would be the result of the transition from a Mott-Hubbard to a forbidden energy gap conductivity regimes. However, this possibility seems to be in conflict with the observation of temperature independent paramagnetic susceptibility. In view of the present study the transport properties of this quite unique salt certanly deserve further attention.

\section{Acknowledgments.}

We are greatly indebted with $\mathrm{V}$. Laukhin (Chernogolovka) for an invaluable discussion concerning the physical propertres of (BEDT-TTF $)_{4} \mathrm{PtCl}_{6} \cdot \mathrm{C}_{6} \mathrm{H}_{5} \mathrm{CN}$. E.C. thanks J. Fontcuberta (Barcelona) and J.-P. Pouget (Orsay) for several discussions during this work. R.P.S. thanhs the Ministère de l'Education Supérieure et de la Recherche (France) for a Senıor Visıting Scientist fellowship, Patrick Batail and all the members of his group for their kind hospitality in Orsay, and the Russian Foundation for Fundamental Research (Gr. n 93-03-18312).

\section{References}

11] Willıams J. M.. Schultz A., Geiser U., Carlson K. D., Kinı A. M., Wang H.-H., Kwok W.-K., Whangbo M.-H., Schirber J. E., Science 251 (1991) 1501.

[2] Ishiguro T.. Yamaji K.. Organic Superconductors (Sprınger-Verlag, Berlin, 1990)

[3] Willıams J. M., Ferraro J. R., Thorn R. J., Carlson K. D., Geiser U., Wang H.-H., Kinı A. M., Whangbo M.-H., Organic Superconductors (Prentice Hall, New Jersey, 1992).

[4] Kinı A. M.. Geiser U., Wang H.-H., Carlson K. D., Williams J. M., Kwok W. K., Vandervoot K. G., Thompson J. E., Stupka D. L., Jung D., Whangbo M.-H., Inorg. Chem. 29 (1990) 2555.

[5] Shıbaeva R. P., Rozenberg L. P., Yagubskii E. B., Kushch N. D., Crystallogr. Rep. 38 (1993) 474.

[6] Willıams J. M., Kini A. M., Wang H.-H., Carlson K. D., Geiser U., Montgomery L. K., Pyrka G. L., Watkins D. M., Kommers J. M., Boryschuk S. J., Crouch A. V. S., Kwok W. K., Schirber J. E., Overmyer D. L., Jung D., Whangbo M.-H., Inorg. Chem. 29 (1990) 3272.

171 Papavassilıou G. C., Mousdis G. A., Zambounis J. S., Terzis A.. Hountas S., Hilı B.. Mayer C.. Pfeiffer W., J. Synth. Met. 27 (1988) B379.

[8] Blanchard P., Boubekeur K., Sallé M., Duguay G., Jubault M., Gorgues A., Martın J. D., Canadell E., Auban-Senzier P., Jérome D., Batail P., Adv Mat. 4 (1992) 579.

[9] Jung D., Evain M., Novoa J. J., Whangbo M.-H., Beno M. A., Kinı A. M., Schultz A. J., Williams J. M., Nigrey P. J., Inorg. Chem. 28 (1989) 4516.

[10] Galimzyanov A. A., Ignatev A. A., Kushch N. D., Laukhın V. N., Makova M. K., Merzhanov V. A., Rozenberg L. P., Shibaeva R. P., Yagubskii E. B., Synth. Met. 33 (1989) 81.

[11] Korotkov V. E., Molchanov V. N., Shibaeva R. P., Sov Phys Crystallogs. 37 (1972) 776.

[12] Whangbo M.-H., Hoffmann R., I. Am Chem Soc. 100 (1978) 6093.

[13] Hoffmann R., I. Chem. Phys. 39 (1963) 1397.

A modified Wolfsberg-Helmholz formula (Ammeter J., Bürgi H.-B., Thibeault J., Hoffmann R., I Am. Chem. Soc 100 (1978) 3686) was used to evaluate the nondiagonal $\mathrm{H}_{\mu}$, values.

[14] Clementı E., Roetti C., At. Nucl. Data Tables 14 (1974) 177.

[15] Pénıcaud A., Boubekeur K., Bataıl P., Canadell E., Auban-Senzıer P., Jérome D., I. Am. Chem. Soc. 115 (1993) 4101.

[16] (a) Whangbo M.-H., Willams J. M., Leung P. C. W., Beno M. A., Emge T. J., Wang H.-H., Inorg. Chem. 24 (1985) 3500.

(b) Williams J. M., Wang H.-H., Emge T. J., Geiser U., Beno M. A., Leung P. C. W., Carlson K. D., Thorn R. J., Schultz A. J., Whangbo M.-H., Prog Inorg. Chem. 35 (1987) 51. 
(c) Since overlap s explıcitely included in extended Hückel calculatıons, these interaction energıes $(\beta)$ should not be confused with the conventional transfer integrals $(t)$. Although the two quantities are obviously related and have the same physical meaning, the absolute values of $\beta$ are somewhat greater than those of $t$.

[17] Kobayashı H., Kobayashı A.. Sasaki Y., Saito G.. Inokuchı H., Bull Chen. Sox Ipn 59 (1986) 301.

[18] Geiser U., Wang H.-H., Gerdom L., Firestone M. A., Sowa L.. Willams J. M., Whangbo M.-H.. I. Am. Chem. Soc. 107 (1985) 8305.

[19] Shibaeva R. P., Kamınskii V. F., Bel'skii V. K., Soc. Phss Colsallogr 29 (1984) 638.

[20] Albright T., Burdett J. K.. Whangbo M.-H., Orbital Interactions in Chemistry (Wiley-Interscience, New York, 1984).

121] Because overlap is explicitely included in our extended Hückel calculations. the $\beta$ interaction energies have to be corrected by an overlap term which makes them smaller. Thus the effective interaction matrix elements are smaller than the values in table Il

[22] Shaik S. S., Whangbo M.-H., Inolg Chem 25 (1986) 1201 